\title{
SIFAT FISIK DAN MEKANIK PAPAN SEMEN DARI LIMBAH PENGGERGAJIAN BERDASARKAN UKURAN PARTIKEL DAN KOMPOSISI SEMEN
}

\author{
(Physical And Mechanical Properties Of Cement Boards From Sawing Waste Based On \\ Particle Sizes And Cement Composition)
}

\author{
Muhammad Aprizal Syaifudin, M. Dirhamsyah, Evy Wardenaar \\ Fakultas Kehutanan Universitas Tanjungpura Jl. Daya Nasional, Pontianak 78124 \\ e-mail: muhammadaprizal.fahutan@gmail.com
}

\begin{abstract}
This study aims to examine the physical and mechanical properties of cement boards from sawing waste based on raw material composition and particle size, as well to get the best sawing waste particle size and raw material composition according to JIS A5417-1992 standard. The research was carried out at the Wood Workshop Laboratory, Wood Technology Laboratory, Wood Processing Laboratory and PT Duta Pertiwi Nusantara Pontianak. This study uses a completely randomized factorial design (CRD) with two factors, namely factor $A$ (Particle Size) and factor B (composition of cement). The results showed the average value of density ranged from 0.6878 to $0.8094 \mathrm{gr} / \mathrm{cm}^{3}$, moisture content value ranged from 6.7057 to $10.0246 \%$, thickess swelling value ranged from 0.3996 to $0.8773 \%$, water absorption value ranged from 27.8949 - 49.0375\%, MOE ranged from $412.6563-1411.7847 \mathrm{~kg} / \mathrm{cm}^{2}$ and MOR value ranged from $2.1529-4.5909 \mathrm{~kg} / \mathrm{cm}^{2}$. The particle size that affects the physical properties is the value of water absorption, while the composition of the material that affects the physical properties is the density, water content, thickness development and water absorption capacity. The particle size and composition of the material which influence the mechanical properties, namely the value of the flexural firmness and fracture firmness. Based on the results of cement board testing with particle composition and cement (1:2) with particle size passing 10 mesh restrained 20 mesh yields the best physical properties of cement board that meet the standards of JIS A 5417: 1992, while none of the cement boards MOE and MOR meet the testing standards mechanical properties according to JIS A 5417: 1992.
\end{abstract}

Keywords: Cement board, composition of cement, particle size, sawing waste.

\section{PENDAHULUAN}

Di Indonesia ada tiga macam industri kayu yang secara dominan mengkonsumsi kayu dalam jumlah relatif besar yaitu penggergajian, vinir (kayu lapis) dan pulp (kertas). Masalahnya adalah limbah penggergajian pada kenyataan dilapangan masih banyak yang menumpuk, sebagian dibuang ke aliran sungai dan dibakar sehingga menimbulkan pencemaran terhadap lingkungan. Indonesia banyak terdapat pabrik industri pengolahan kayu dan industri pengergajian kayu skala kecil yang menghasilkan limbah yang besar. Menurut Purwanto (2009) besarnya limbah yang dihasilkan dari industri penggergajian kayu rata-rata pertahun sebesar 40,48\% volume, dengan rincian sabetan 22,32\%, potongan kayu 9,39\% dan serbuk gergaji 8,77\%.

Kalimantan Barat terdapat banyak industri penggergajian yang menghasilkan 
limbah yang tidak dipisahkan antar jenis kayu yang digergaji. Oleh karena itu pemanfaatan serbuk gergaji merupakan salah satu limbah hasil industri yang dapat dimanfaatkan sebagai bahan baku untuk pembuatan papan mineral (papan semenserbuk gergaji) perlu dilakukan.

Bakri et al. (2006) mengatakan limbah industri penggergajian merupakan bagian dari kayu yang diperoleh dari hasil proses penggergajian yang bentuk, ukuran dan cacat yang tidak dapat digunakan lagi untuk sortimen kayu gergajian. Limbah industri penggergajian kayu dapat berupa serbuk gergaji (sawdust), sabetan (slabs), potongan-potongan (trims), dan serutan (skaring). Limbah serbuk kayu banyak menimbulkan masalah dalam penanganannya yang selama ini dibiarkan membusuk, ditumpuk, dan dibakar yang akan menimbulkan dampak negatif terhadap lingkungan.

Meningkatnya kebutuhan kayu secara signifikan menimbulkan permasalahan yang harus diselesaikan bersama, salah satu solusinya adalah pemanfaatan bahan baku limbah industri pengggergajian kayu. Salah satu bahan bangunan yang mampu memenuhi masa sekarang tanpa mengganggu pemenuhan kebutuhan dimasa mendatang adalah bahan bangunan dengan pemanfaatan limbah gergajian yang tidak dimanfaatkan lagi.

Menurut Dirhamsyah (2011), hasil penelitian tentang sifat papan semen partikel kayu karet dengan ukuran lolos saringan 6 mesh tertahan 8 mesh (partikel halus) menghasilkan sifat fisik dan mekanik yang terbaik dan semakin tinggi kadar semen yang digunakan maka nilai
MOE semakin meningkat dibandingkan dengan ukuran lolos 2 mesh tertahan 4 mesh (partikel kasar) dan ukuran lolos 4 mesh tertahan 6 mesh (partikel sedang). Dengan demikian ikatan antara partikel dan semen serta antara partikel itu sendiri akan semakin kuat dan lebih rapat, sehingga keteguhan lentur (MOE) juga akan meningkat. Penelitian yang dilakukan oleh Armaya et al. (2013) menyatakan bahwa papan semen dari partikel bambu dengan ukuran 40 mesh memiliki kerapatan yang cukup tinggi dibandingkan dengan ukuran partikel 20 mesh.

Menurut Purwanto (2014) hasil penelitian pembuatan papan semen dengan perbandingan kulit kayu gelam dan semen masing-masing $1: 1, \quad 1: 1,5$ dan $1: 2$ didapatkan perbandingan campuran kulit kayu dan semen yaitu 1:2 dengan panjang kulit kayu $2 \mathrm{~cm}$ menghasilkan kadar air, pengembangan tebal, penyerapan air, kerapatan, keteguhan patah /MOR, keteguhan lentur/MOE dan keteguhan tarik yang terbaik, dan memenuhi standar JIS A 5417-1992.

Dari hasil penelitian tersebut maka perlu dilakukan penelitian membuat papan semen dengan memanfaatkan limbah penggergajian dengan ukuran partikel lolos 10 mesh tertahan 20 mesh dan lolos 20 mesh tertahan 40 mesh, sedangkan perbandingan komposisi yang digunakan antara partikel dan semen adalah 1:1, 1:1,5 dan 1:2. Tujuan dari penelitian yaitu untuk menguji sifat fisik dan mekanik papan semen dari limbah penggergajian berdasarkan komposisi bahan baku dan ukuran partikel, selain itu juga untuk mendapatkan ukuran partikel limbah 
penggergajian dan komposisi bahan baku terbaik sesuai dengan standar JIS A54171992. Manfaat dari penelitian ini adalah untuk memberikan informasi bahan baku alternatif pemanfaatan limbah penggergajian sebagai produk papan semen.

\section{METODE PENELITIAN}

Penelitian dilaksanakan di Laboratorium Wood Workshop Fakultas Kehutanan Universitas Tanjungpura untuk persiapan bahan baku, Laboratorium Teknologi kayu, Laboratorium Pengolahan Kayu Fakultas Kehutanan Universitas Tanjugpura untuk pembuatan papan semen dan PT Duta Pertiwi Nusantara Pontianak untuk melakukan pengujian papan. Waktu penelitian yaitu selama \pm 2 bulan mulai dari persiapan sampai pengolahan data. Alat yang digunakan yaitu cetakan berukuran $30 \mathrm{~cm}$ x $30 \mathrm{~cm}$ x $1 \mathrm{~cm}$, sendok semen untuk mencampurkan bahan, timbangan analitik untuk menimbang bahan, jam untuk meghitung waktu, kamera untuk mengambil gambar, kaliper (jangka sorong) untuk mengukur papan semen, ayakan untuk menyaring serbuk kayu dengan ukuran lolos 10 mesh tertahan 20 mesh dan lolos 20 mesh tertahan 40 mesh, thermometer untuk mengukur suhu hidrasi, tabung reaksi untuk tempat pengujian suhu hidrasi, termos air panas untuk tempat pengujian bahan hidrasi, oven untuk mengurangi kadar air, bak plastik untuk mencampurkan semua bahan, kempa manual, mesin gerinda, mesin UTM untuk penguji papan semen. Bahan yang digunakan yaitu limbah partikel serbuk gergajian, semen Portland tipe 1 (Holcim),
Air, minyak pelumas, katalisator kapur padam $\left(\mathrm{Ca}(\mathrm{OH})_{2}\right)$.

\section{Pengujian Suhu Hidrasi}

Pengukuran suhu hidrasi mengacu pada metode Sanderman (Kamil, 1970). Contoh uji hidratasi yaitu perbandingan antara semen, air, bahan dan katalisator yaitu 200 gr, 100 gr, 20 gr dan 2,5\% dari semen. Semua bahan dicampurkan menjadi satu adonan dan dimasukan ke dalam termos, selanjutnya masukan tabung reaksi kedalam termos yang sudah dimasukan pelumas (oli MPX) sebanyak 1/4 tabung, kemudian thermometer dimasukan kedalam tabung reaksi melalui gabus yang ditutup ke mulut termos. Pengamatan kenaikan suhu dicatat selama 24 jam dengan mencatat perubahan suhu setiap 1 Jam dan yang digunakan sebagai ukuran adalah suhu maksimum.

\section{Persiapan Bahan}

Limbah gergajian yang di dapat dari tempat Sawmil Sari Pasifik jalan Adisucipto Gang Sagu dalam keadaan kering kemudian direndam dengan air dingin selama 24 jam, hal ini bertujuan untuk menghilangkan zat ekstraktif yang ada pada kayu (Kamil, 1970), selanjutnya dijemur dibawah sinar matahari dan di kering udarakan hingga kadar air 9-16\%, sedangkan kadar air yang didapatkan dari hasil penelitian yaitu 13\%. Perlakuan penelitian yang digunakan adalah ukuran serbuk limbah gergajian (A) ada dua yaitu (a1) dengan ukuran lolos 20 mesh tertahan 40 mesh dan (a2) dengan ukuran lolos 10 mesh tertahan 20 mesh dan kemudian komposisi antara bahan baku dengan semen (B) yang di kering udarakan hingga dengan kadar air tertentu. Semen diayak 
dengan ukuran 60 mesh sehingga didapat semen yang seragam dan halus dengan perbandingan komposisi serbuk dan semen (b1, b2, b3 yaitu 1:1, 1:1,5 dan 1:2). Jumlah air yang digunakan yaitu $80 \%$ dari semen, sedangkan katalisator yang digunakan kapur padam menurut yaitu 2,5\% dari semen (Kasmudjo, 1985).

\section{Pembuatan Papan}

Semen dan partikel dimasukan kedalam baskom kemudian tambahkan air yang sudah dicampurkan katalisator dan aduk hingga merata. Bahan yang sudah tercampur rata dimasukan kedalam cetakan dengan ukuran $30 \mathrm{~cm}$ x $30 \mathrm{~cm}$ x $2,5 \mathrm{~cm}$ dan diratakan, kemudian diberi penutup dengan ukuran $30 \mathrm{~cm}$ x $30 \mathrm{~cm} \mathrm{x}$ $1,5 \mathrm{~cm}$. Cetakan selanjutnya dimasukan kedalam alat kempa dingin sehingga cetakan dengan tebal $2,5 \mathrm{~cm}$ tertekan dengan penutup setebal $1,5 \mathrm{~cm}$, sehingga mendapatkan ketebalan $1 \mathrm{~cm}$ selama 3 menit, kemudian diklem selama 24 jam. Papan semen yang telah jadi selanjutnya dikering anginkan pada ruangan terbuka yang tidak terkena sinar matahari langsung selama 2 minggu agar papan semen mengeras dengan sempurna.

\section{HASIL DAN PEMBAHASAN}

\section{Suhu Hidrasi}

Suhu hidrasi merupakan indikator untuk menentukan kesesuaian sebagai bahan baku pembuatan papan semen partikel. Nilai maksimum pengujian suhu hidrasi dengan metode Sanderman (Kamil, 1970 dalam Armaya et al. 2013) yang diperoleh dari hasil pengamatan yang dilakukan selama 24 jam yaitu sebesar $51^{\circ} \mathrm{C}$ pada jam ke-10. Suhu hidrasi mulai mengalami kenaikan pada jam ke- 9 yaitu sebesar $7^{\circ} \mathrm{C} / \mathrm{Jam}$. Naiknya suhu pada pengujian hidrasi disebabkan oleh adanya reaksi eksotermik antara semen, partikel dan air. Suhu hidrasi mengalami stagnan pada jam ke-10, jam ke-11 dan jam ke-12 pada angka maksimum yaitu $51^{\circ} \mathrm{C}$ dan kembali menurun pada jam ke-13 dan seterusnya. Grafik hasil pengujin suhu hidrasi partikel limbah penggergajian disajikan pada Gambar 1.

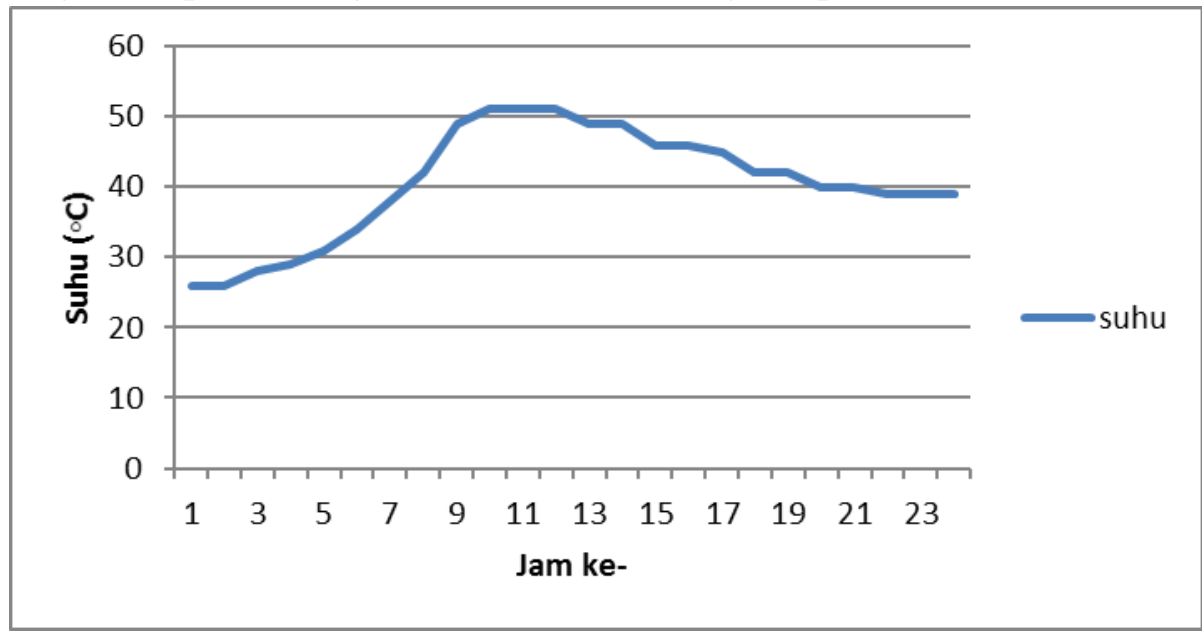

Gambar 1. Grafik Perubahan Suhu Hidrasi Bahan Baku Partikel (Graphs of Changes in Hydration Temperature of Particle Raw Materials)

Berdasarkan dari hasil pengujian tersebut diketahui bahwa partikel limbah penggergajian yang digunakan memberikan pengaruh baik sebagai 
agregat. Dengan demikian menunjukan bahwa partikel limbah penggergajian tidak mengandung banyak zat ekstraktif yang dapat menghambat pengerasan semen, sehingga ikatan antara semen dan partikel dapat terjadi dengan baik.

Sifat Fisik Dan Mekanik Papan Semen

\section{Kerapatan}

Kerapatan adalah sifat fisik yang menunjukan kekompakan ikatan partikel dalam suatu panil, kerapatan merupakan massa atau berat per satuan volume (Haygreen dan bowyer, 1989).Pada umumnya semakin tinggi kerapatan papan maka semakin tinggi sifat mekaniknya. Hasil pengujian papan semen partikel limbah penggergajian menunjukan nilai rerata kerapatan berkisar antara 0,6878 $0,8094 \mathrm{gr} / \mathrm{cm}^{3}$.

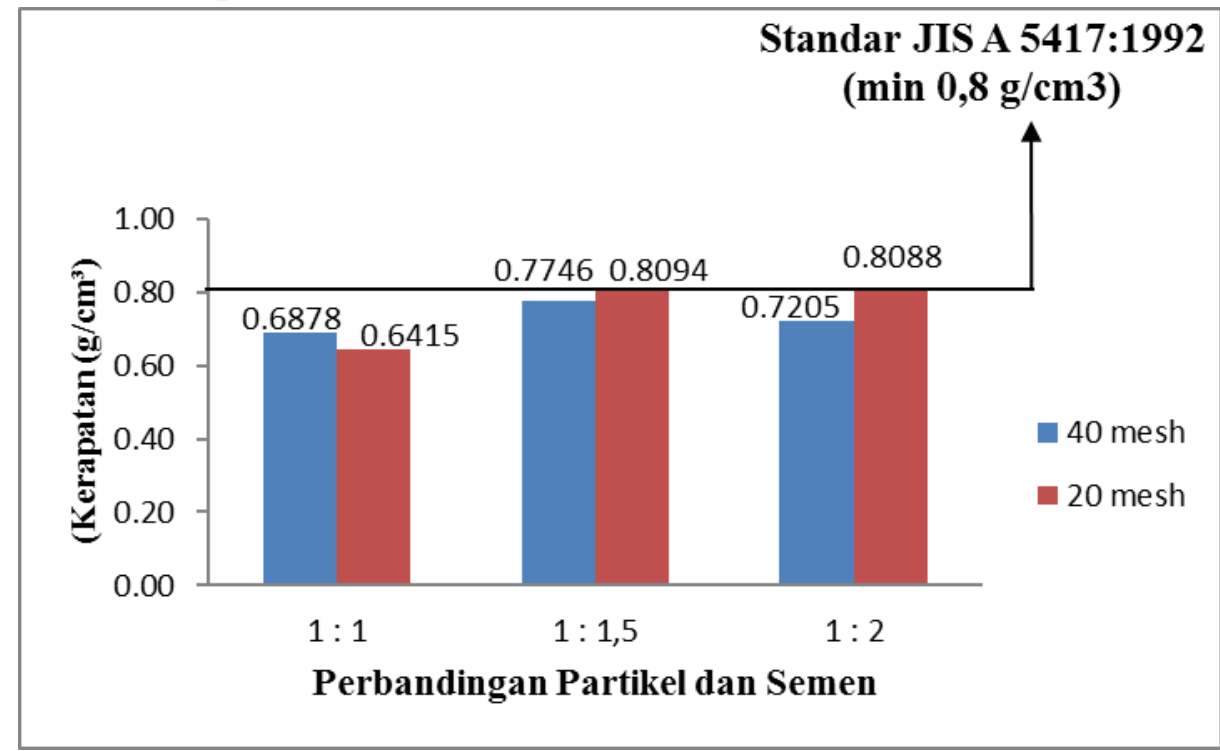

Gambar 2. Grafik Nilai Rerata Kerapatan Papan Semen Partikel (Graph of Average Value of Particle Cement Board Density)

Rata-rata nilai pengujian kerapatan papan semen tidak memenuhi target kerapatan yang diinginkan yaitu sebesar 1 $\mathrm{gr} / \mathrm{cm}^{3}$, hal tersebut dikarenakan semen yang bersifat padat dengan kadar tertentu tidak mampu mengikat sempurna dengan jumlah air yang digunakan. Hal tersebut diduga saat pelepasan dari cetakan dan klem papan mengembang kembali, sehingga susunan komponen bahan dalam papan tidak rapat dan adanya pori-pori yang terbuka sehingga tebal papan semen menjadi besar sementara kerapatan akan menjadi kecil. Menurut Sembiring et al.
(2015) dalam penelitianya dengan membuat papan semen yang diklem selama 4 hari menyatakan nilai kerapatan papan semen rendah akibat dari ketebalan papan melebihi ketebalan target yang di tetapkan. Menurut Purwoko (1980) mengatakan bahwa jumlah air yang digunakan untuk sejumlah semen akan menentukan kualitas adukan campuran yang dihasilkan. Hal ini menyebabkan ikatan antara semen dan partikel menjadi kurang kompak sehingga nilai kerapatan papan semen yang dihasilkan cenderung rendah. 
Nilai rerata kerapatan yang didapat menunjukan papan semen partikel dengan ukuran 40 mesh lebih rendah dari partikel dengan ukuran 20 mesh. Hal tersebut sejalan dengan penelitian Simbolon et al. (2015) yang menyatakan nilai kerapatan papan semen dengan ukuran partikel 80 mesh lebih rendah dari papan semen dengan ukuran partikel 30 mesh disebabkan ukuran partikel yang sangat halus tidak dapat diikat dengan baik oleh semen dan memiliki ikatan kurang erat untuk rasio massa partikel dan semen yang digunakan. Hasil yang didapatkan dalam penelitian ini sejalan dengan penelitian Purwanto (2014) yang membuat papan semen dengan perbandingan kulit kayu gelam dan semen dengan perbandingan campuran kulit kayu dan semen yaitu 1:2 menghasilkan nilai terbaik yang memenuhi standar pengujian JIS A 5417:1992.

\section{Kadar Air}

Hasil pengujian papan semen partikel limbah penggergajian menunjukkan nilai rerata kadar air berkisar antara 6,705710,0246\%. Nilai rerata kadar air papan semen dapat dilihat pada Gambar 3.

Standar JIS A 5417:1992 $(\leq 16 \%)$

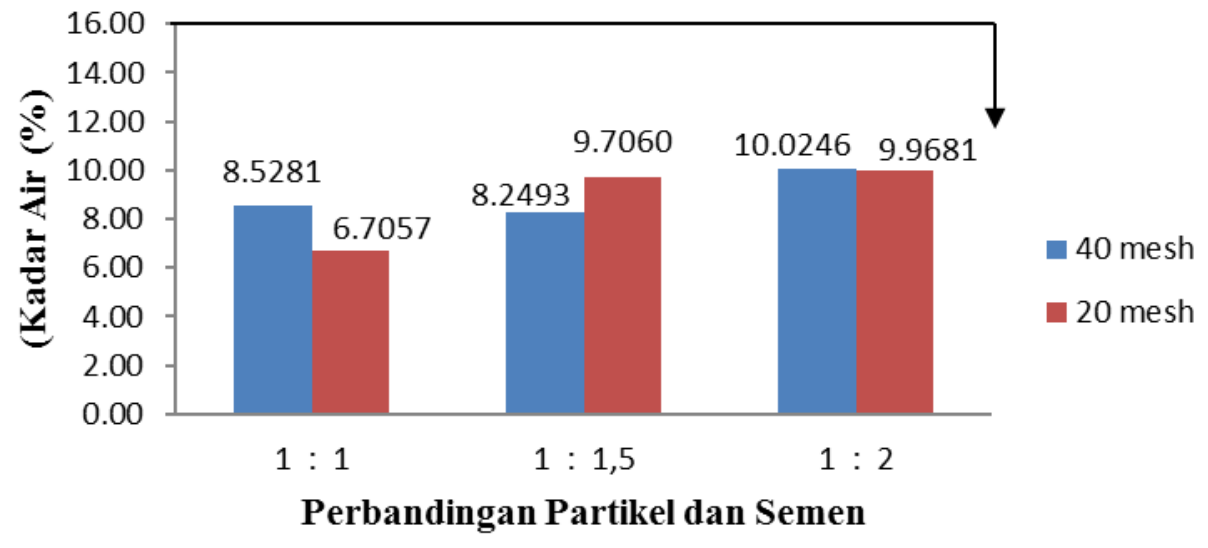

Gambar 3. Grafik Nilai Rerata Kadar Air Papan Semen Partikel (Graph of Average Value Moisture Content of Cement Particle Board)

Nilai kadar air papan semuanya memenuhi standar pengujian JIS A 5417:1992 yaitu $\leq 16 \%$. Kadar air tertinggi yang dihasilkan dari papan semen dengan perlakuan komposisi partikel dan semen (1:2) yaitu sebesar 13,9132\%. Hal ini diduga semakin banyak penggunaan semen dalam penggunaan papan akan menambah penggunaan air didalam pembuatan adonan papan semen. Diduga air yang tertahan didalam papan akan sulit untuk menguap karena rapatnya komponen penyusun sehingga kadar air juga akan meningkat. Hal tersebut sejalan dengan penelitian Hendrik (2005) yang menyatakan semakin tinggi kadar semen yang digunakan maka semakin tinggi pula kadar air yang dihasilkan.

Berdasarkan hasil penelitian pada Gambar 3 dapat dilihat bahwa papan 
semen yang dibuat dengan partikel ukuran kecil pada umumya menghasilkan kadar air yang lebih tinggi dibandingkan dengan partikel ukuran besar. Menurut Simbolon et al. (2015) bahwa ukuran partikel besar (30 mesh) menghasilkan kadar air yang lebih rendah dari partikel ukuran kecil (80 mesh) hal ini dikarenakan ukuran partikel yang besar membutuhkan banyak semen untuk mengikat partikel.

Kadar air tertinggi yang dihasilkan dari papan dengan ukuran partikel lolos 20 mesh tertahan 40 mesh dengan perbandingan komposisi semen dan partikel (1:2) yaitu sebesar 13,9132\%. Hal ini diduga karena jumlah partikel dengan ukuran besar yang sedikit dengan perbandingan semen yang banyak menyebabkan air sulit untuk menyerap menyebabkan kadar air lebih rendah. Hal ini sesuai dengan pernyataan Bakri et al. (2006) bahwa jumlah partikel yang sedikit akan sulit menyerap air dengan proporsi semen yang lebih tinggi, akibatnya kadar air lebih rendah. Oleh karena itu maka kadar air komposisi semen partikel 1:2 dangan ukuran kecil (40 mesh) lebih tinggi dibandingkan dengan ukuran besar (20 mesh).

\section{Pengembangan Tebal}

Perubahan dimensi papan dalam hal ini ketebalan menjadi penting dalam banyak pemakaiannya. Stabilitasi dimensi papan akan rendah apabila pengembangan tebal papan tinggi. Pengembangan tebal bukanlah suatu proses yang seketika tapi membutuhkan waktu setelah papan menjadi basah (Haygreen dan bowyer, 1989). Menurut Armaya et al. (2013) pengembangan tebal adalah sifat fisik untuk menentukan penggunaan suatu papan semen untuk keperluan baik eksterior maupun interior. Hasil dari pengujian papan semen partikel berkisar antara 0,3996-0,8773\%. Hasil rekapitulasi rerata papan semen dapat dilihat pada Gambar 4.

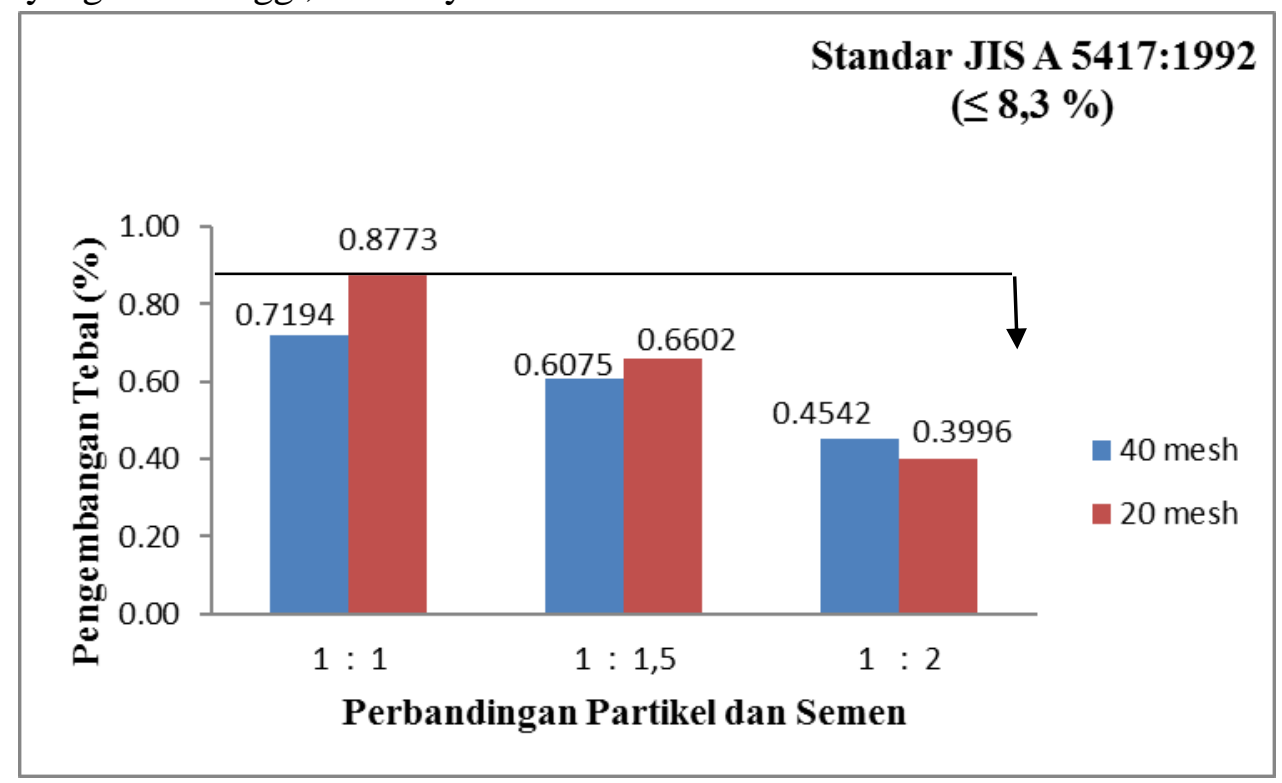
Gambar 4. Grafik Nilai Rerata Pengembangan Tebal Papan Semen Partikel (Graph of Average Development Value of Particle Cement Board Thickness)


Standar JIS A 5417:1992 dengan syarat pengembangan tebal papan \pm $8,3 \%$, secara keseluruhan nilai pengembangan tebal papan semen dari hasil penelitian memenuhi standar pengujian. Pada Gambar 4 menunjukan bahwa pengembangan tebal dipengaruhi oleh banyaknya air yang mampu diserap oleh papan.

Berdasarkan dari hasil penelitian dapat dilihat bahwa adanya penurunan pengembangan tebal seiring dengan bertambahnya komposisi semen yang terkandung didalam papan semen partikel. Hal tersebut juga didukung dari hasil penelitian Prayitno (2001) dalam Simbolon et al. (2015) yang menyatakan semakin tinggi kadar semen yang digunakan maka nilai pengembangan tebal akan semakin menurun. Nilai pengembangan tebal tertinggi dihasilkan dari papan semen dengan komposisi partikel dan semen (1:1) dan ukuran partikel lolos 10 mesh tertahan 20 mesh yaitu sebesar $0,9328 \%$. Hal ini diduga karena papan memiliki komposisi semen yang sebanding dengan komposisi partikel sehinggan menyebabkan bahan pengikat tidak mampu mengikat partikel dengan baik dan mengakibatkan pengembangan tebal menjadi lebih besar. Menurut Mujahid (2010) semakin besar ukuran serbuk maka akan menyebabkan nilai kerapatan semakin menurun, karena partikel besar mengakibatkan kontak yang lemah sehingga menciptakan rongga diantara partikel.

Nilai pengembangan tebal terkecil dihasilkan dari papan semen dengan komposisi parikel dan semen (1:2) dan ukuran partikel lolos 10 mesh tertahan 20 mesh yaitu sebesar 0,6250\%. Hal tersebut diduga komposisi semen yang lebih banyak mampu mengikat partikel dengan baik. Menurut Simbolon et al. (2015) dengan menggunakan partikel cangkang kemiri menyatakan bahwa semakin banyak komposisi semen yang digunakan maka semakin banyak partikel yang dapat diikat oleh semen.

Daya Serap Air

Daya serap air yaitu salah satu sifat fisik papan semen yang menunjukan kemampuan papan untuk menyerap air dalam jangka waktu tertentu. Fatriasari dan Hermiati (2006) dalam Sibarani (2011) menyatakan bahwa besarnya nilai daya serap air dipengaruhi oleh besar diameter serat dan panjang serat partikel yang digunakan. Hasil pengujian daya serap air menunjukan nilai rerata yaitu berkisar antara 27,8949 - 49,0375\%. Nilai rerata daya serap air papan semen dapat dilihat pada Gambar 5. 


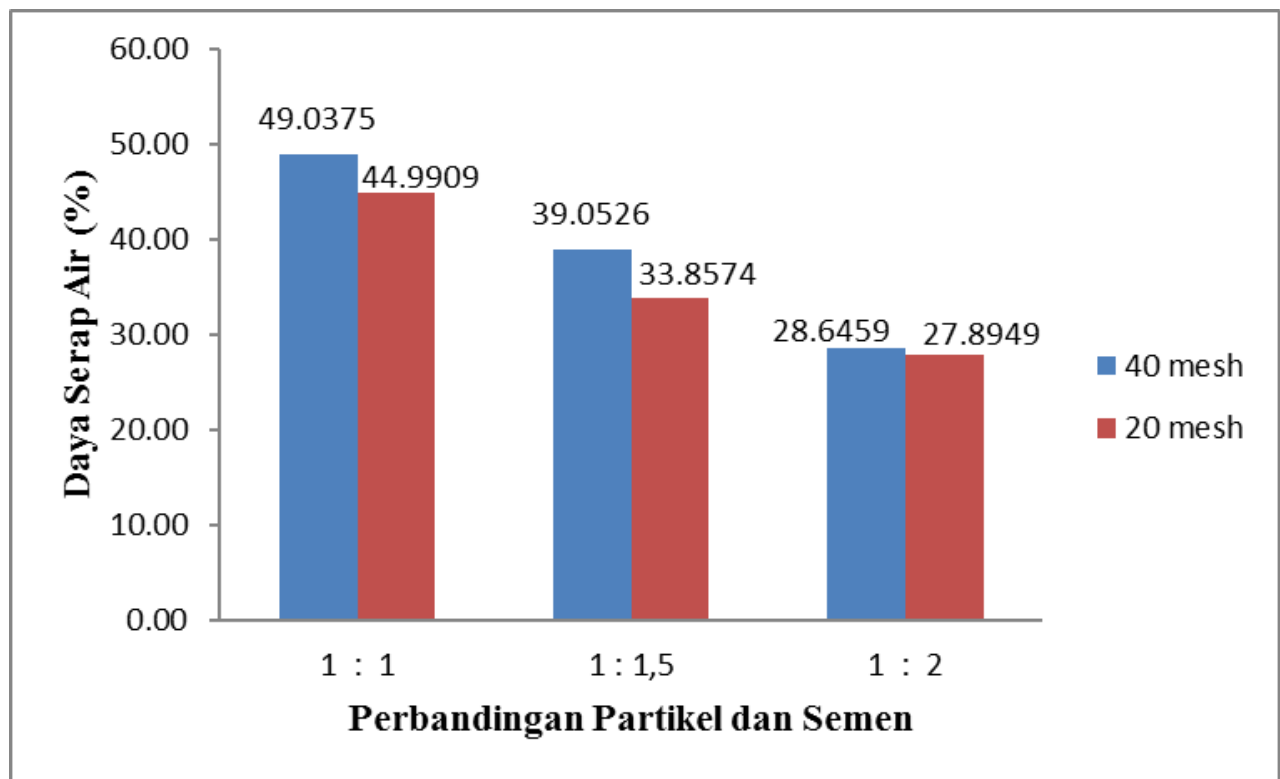

Gambar 5. Grafik Nilai Rerata Daya Serap Air Papan Semen Partikel (Graph of Average Value of Water Absorption of Cement Particle Board)

Pengujian daya serap air dilakuan karena berpengaruh terhadap ketahanan suatu hasil papan semen dalam penggunaannya yang berhubungan langsung dengan cuaca. Dari hasil penelitian menunjukan bahwa adanya penurunan daya serap air seiring dengan bertambahnya komposisi semen yang terkandung dalam papan. Hal tersebut dikarenakan semakin tinggi komposisi semen maka semakin baik untuk mengikat partikel sehingga sulit untuk ditembus oleh air. Menurut Kumoro (2007) dalam Sembiring (2015) menyatakan bahwa lapisan perekat semen yang tebal akan membentuk daya adhesi antara perekat semen dengan partikel dan daya kohesi antar partikel semakin kuat, akibatnya air sukar menembus lapisan semen yang tebal dan struktur papan semen partikel yang rapat.

Nilai daya serap air tertinggi dihasilkan dari perlakuan dengan komposisi parikel dan semen (1:1) dan ukuran partikel lolos 20 mesh tertahan 40 mesh yaitu sebesar 49,0375\%. Papan dengan perlakuan ini diduga perbandingan partikel dan semen yang sama sehingga menyebabkan ikatan antara komponen tidak kuat, sehingga mudah ditembus oleh air. Nilai daya serap air terkecil yaitu dari perlakuan komposisi partikel dan semen (1:2) dan ukuran partikel lolos 10 mesh tertahan 20 mesh yaitu sebesar $27,8949 \%$. Hal tersebut diduga papan dengan perbandingan semen yang lebih banyak dari partikel akan membuat ikatan antara komponen akan menjadi lebih kuat sehingga hanya sedikit rongga yang dapat ditembus oleh air.

Pengujian Modulus of Elastisity (MOE)

Hasil pengujian papan semen partikel menujukan bahwa nilai MOE yang didapatkan yaitu berkisar antara 412,6563-1411,7847 $\mathrm{kg} / \mathrm{cm} 2$. Rekapitulasi rerata nilai MOE dapat dilihat pada Gambar 6. 


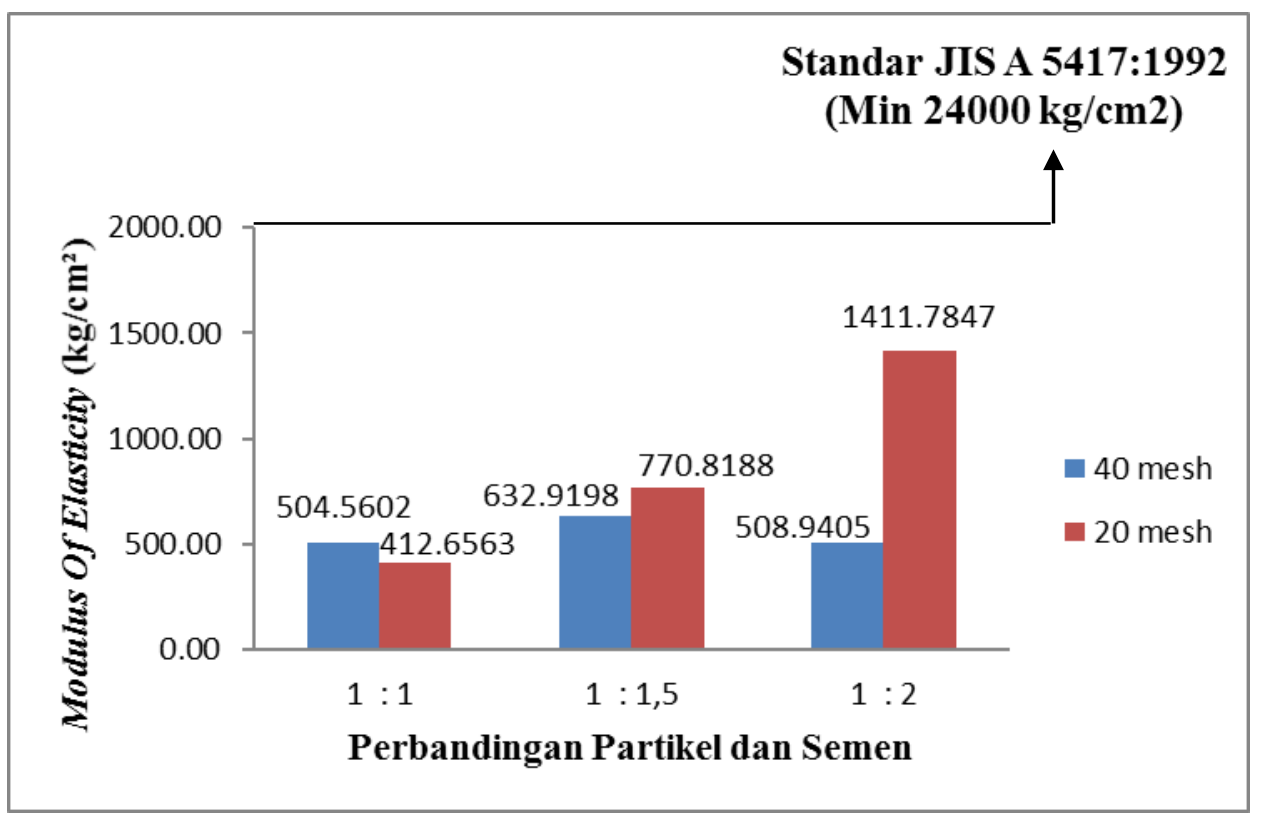

\section{Gambar 6. Grafik Nilai Rerata MOE Papan Semen Partikel ( Graph Average Value of MOE Cement Particle Board)}

Dari hasil penelitian menunjukan bahwa tidak ada satu pun papan yang memenuhi standar JIS A 5417:1992 yang mensyaratkan nilai MOE $>24.000$ $\mathrm{kg} / \mathrm{cm} 2$. Papan semen dengan nilai tertinggi adalah papan dengan komposisi partikel dan semen (1:2) dan ukuran partikel lolos 10 mesh tertahan 20 mesh yaitu sebesar $1411,7847 \mathrm{~kg} / \mathrm{cm} 2$. Hal tersebut diduga karena semakin halus ukuran partikel maka akan semakin kurang ikatan antara partikel dan semen. Hal tersebut sejalan dengan penelitian Hamdi et al. (2010) membuat papan partikel kayu dengan ukuran 60 mesh lebih baik dibandingkan dengan ukuran 80 mesh. hal tersebut dikarenakan semakin halus ukuran partikel maka akan semakin kurang ikatan antara partikel dan semen. Menurut Hakim dan Sucipto (2012) semen memegang peranan penting dalam sistem perekatan antar serat, sehingga semakin banyak semen maka semakin baik perekatannya.

PengujianModulus Of Rupture (MOR)

Hasil pengujian papan semen partikel menunjukan nilai rerata MOR berkisar antara 2,1529-4,5909 kg/cm2. Rekapitulasi rata-rata nilai MOR papan semen partikel dapat dilihat pada Gambar 7. 


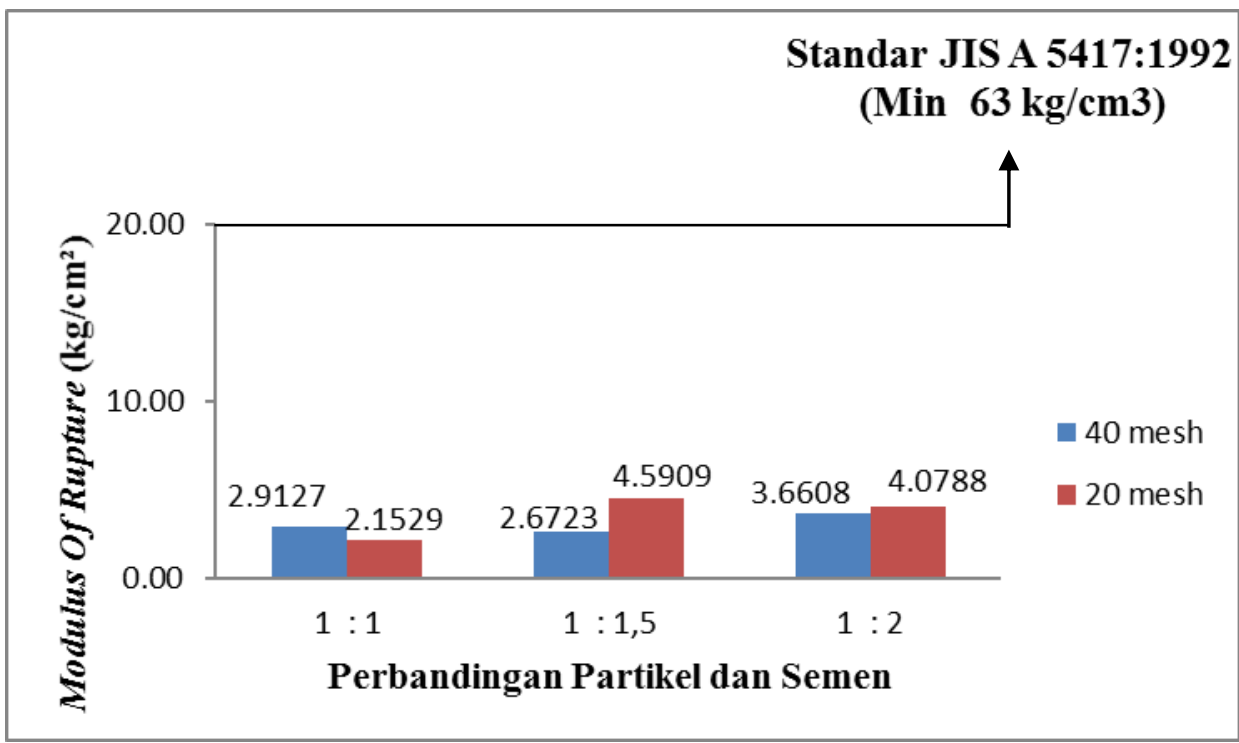

\section{Gambar 7. Grafik Nilai Rerata MOR Papan Semen Partikel (Graph Average Value of MOR Cement Particle Board)}

Berdasarkan hasil penelitian pada Gambar 7 menunjukan bahwa tidak ada nilai MOR papan semen yang memenuhi standar JIS A 5417:1992. Hal ini diduga karena ikatan antar partikel dan semen lemah sehigga hasil yang didapatkan tidak dapat memenuhi standar, selain itu diduga lama waktu pengkleman papan semen juga mempengaruhi hasil yang didapatkan. Menurut Haygreen dan bowyer (1989) menyatakan semakin tinggi kerapatan partikel penyusunnya, maka akan semakin tinggi keteguhan papan partikel yang dihasilkan.

Berdasarkan hasil peneliian menunjukan bahwa papan dengan pemberian ukuran partikel besar (20 mesh) memiliki nilai MOR yang lebih tinggi dibandingkan dengan ukuran kecil (40 mesh). Hal tersebut diduga karena kurangnya ikatan antar partikel dan semen sehingga menimbulkan rendahnya nilai yang dihasilkan.
Menurut Hamdi et al. (2010) papan semen dengan ukuran 60 mesh lebih baik dibandingkan dengan ukuran 80 mesh. Hal tersebut dikarenakan semakin halus ukuran partikel maka akan semakin kurang ikatan antara partikel dan semen.

\section{KESIMPULAN}

Berdasarkan dari hasil penelitian dapat ditarik kesimpulan sebagai berikut:

1. Ukuran partikel yang berpengaruh terhadap sifat fisik yaitu nilai daya serap air, sedangkan komposisi bahan yang berpengaruh terhadap sifat fisik yaitu kerapatan, kadar air, pengembangan tebal dan daya srap air. Ukuran partikel dan komposisi bahan yang meberikan pengaruh terhadap sifat mekanik yaitu nilai keteguhan lentur dan keteguhan patah.

2. Berdasarkan dari hasi pengujian dengan komposisi partikel dan semen 
(1:2) dengan ukuran partikel lolos 10 mesh tertahan 20 mesh menghasilkan sifat fisik papan semen terbaik yang memenuhi standar JIS A 5417:1992, sedangkan MOE dan MOR papan semen tidak ada yang memenuhi standar pengujian sifat mekanik menurut JIS A 5417:1992.

\section{SARAN}

Disarankan dalam melakukan penelitian pembuatan papan semen partikel disimpan ditempat yang baik sehingga tidak terganggu oleh cuaca luar. Papan semen memerlukan waktu klem lebih dari 4 hari agar papan semen tidak mengembang dan dapat mengeras dengan baik.

\section{DAFTAR PUSTAKA}

Armaya R, Herawati E, Sucipyo T. 2013. Karakteristik Fisis Dan Mekanis Papan Semen Bambu Hitam

(Gigantochloa Atroviolacea Widjaja) Dengan Dua Ukuran Partikel. Jurnal Universitas Sumatera Utara. Medan. 4(2):9-15

Bakri, Gunawan E, Sanusi D. 2006. Sifat Fisik dan Mekanik Komposit Kayu Semen Serbuk Gergajian. Jurnal Perennial, 2: 38-41.

Dirhamsyah M. 2011. Sifat Papan Semen Partikel Kayu Karet (Cement Board Property of Rubber Wood Particle). Jurnal Tengkawang. 1:43-50

Hakim, L. dan T. Sucipto. 2012. Pengaruh Rasio Semen/Serat Dan Jenis Katalis Terhadap Kekuatan Fiber-Cement Board Dari Limbah Kertas Kardus. Indonesian Journal Of Forestry Research 1(2): 70-78.
Hamdi S, Arhamsyah. 2010. Sifat Fisis Mekanis Papan Partikel Dari Limbah Kayu Gergajian Berdasarkan Ukuran Partikel. Jurnal riset industri hasil hutan 2(2):13-17

Haygreen JG dan Bowyer JL. 1989. Hasil Hutan dan Ilmu Kayu. Suatu Pengantar (Terjemahan). Yogyakarta. Gajah Mada University Press.

Hendrik. 2005. Pembuatan Papan Semen Gypsum Dari Kayu Akasia Mangium Willd. Fakultas Kehutan IPB. Bogor.

Kamil RN. 1970. Prospek pendirian industri papan wol kayu di Indonesia.Lembaga-lembaga Penelitian Kehutanan Bogor.

Kamil RN, Kliwon S. 1973. Pengujian Enam Jenis Kayu Dari Jasinga Untuk Papan Wol Kayu.Lembaga Penelitian Hasil Hutan Laporan No.18. Bogor.

Kasmudjo. 1985. Papan Semen Cetakan 1, Yayasan Pembina Fakultas Kehutanan, Universitas Gajah Mada. Yogyakarta.

Mujahid, 2010. Sifat Fisik Dan Mekanik Komposit Semen CaCl2 Aren dengan Variasi Ukuran Serat Aren. Prosiding Seminar Nasional Sains dan Teknologi Volume 1, No 1. Fakultas Teknik Universitas Wahid Hasyim Semarang.

Purwanto D. 2009Analisa Jenis Limbah Kayu Pada IndustriPengolahan Kayu Di Kalimantan Selatan. Jurnal Riset Industri Hasil Hutan. 1:14-20.

Purwanto D. 2014. Sifat Fisik dan Mekanik Papan Semen dari Limbah Kulit Kayu 
Gelam.Journal of Industrial Research. 8:197 - 204.

Sembiring DN, Hakim L, Sucipto T. 2015. Kualitas Papan Semen Dari Partikel Serutan Pensil Dengan Berbagai Rasio Semen Dan Partikel. Jurnal Universitas Sumatra Utara. 4(2):175-185

Sibarani, I.P. 2011. Karakteristik Papan Semen Dari Tiga Jenis Bambu
Dengan Penambahan Katalis Magnesium Klorida ( $\mathrm{MgCl}$ ). Universitas Sumatra Utara.

Simbolon, Ira L, Tito S, Rudi H. 2015. Pengaruh Ukuran Partikel dan Komposisi Semen- Partikel Terhadap Kualitas Papan Semen Dari Cangkang Kemiri (Aleurites Moluccana Wild). 